\title{
Thermodynamic properties of Anacardium humile St. Hil. (cajuzinho-do-cerrado) achenes
}

\section{Propriedades termodinâmicas de aquênios de Anacardium humile St. Hil.}

\author{
Karine Feliciano Barbosa ${ }^{1 *}$; Juliana de Fátima Sales ${ }^{2}$; \\ Osvaldo Resende ${ }^{2}$; Daniel Emanuel Cabral de Oliveira ${ }^{3}$; \\ Ana Lúcia Cabral'; Luiz César Lopes Filho ${ }^{5}$
}

\begin{abstract}
The cajuzinho-do-cerrado is a native species of the cerrado of great potential of use and is threatened of extinction. The aim of this study was to determine and evaluate the thermodynamic properties of Anacardium humile St. Hil. achenes from the different hygroscopic equilibrium points according to the moisture content. To obtain the isotherms, the indirect static method was used at temperatures of 10, 20, 30 and $40{ }^{\circ} \mathrm{C}$ and for moisture contents of $13.4,11.1,8.7$ and 5.3\% dry basis (db). The Copace model was used to describe the hygroscopic equilibrium of the achenes. The thermodynamic properties are influenced by the moisture content because the latent heat of vaporization of the water of the achenes increases with the decrease in the equilibrium moisture content, varying between 3,035.63 and 2,510.80 $\mathrm{kJ} \mathrm{kg}^{-1}$ for moisture contents of 4.51 to $13.4 \% \mathrm{db}$, respectively. The differential enthalpy and entropy are closely related to the moisture content of the achenes. The isokinetic temperature of $304.67 \mathrm{~K}$ denotes the linear chemical compensation between the differential enthalpy and entropy of the Anacardium humile St. Hil. achenes, and the desorption process is controlled by enthalpy.
\end{abstract}

Key words: Enthalpy. Entropy. Free energy. Latent heat. Water activity.

\section{Resumo}

O cajuzinho-do-cerrado é uma espécie nativa do cerrado de grande potencial de uso e encontra-se ameaçada de extinção. Objetivou-se determinar e avaliar as propriedades termodinâmicas para diferentes teores de água de equilíbrio higroscópico dos aquênios de cajuzinho-do-cerrado. Para obtenção das isotermas utilizou-se o método estático indireto nas temperaturas de $10,20,30$ e $40^{\circ} \mathrm{C}$ e teores de água de 13,$4 ; 11,1 ; 8,7 ; 5,3 \%$ base seca (b.s.). O modelo de Copace foi utilizado para descrever o equilíbrio higroscópico dos aquênios. As propriedades termodinâmicas são influenciadas pelo teor de água, uma vez que o calor latente de vaporização da água dos aquênios aumenta com o decréscimo do teor de água de equilíbrio, variando entre $3.035,63$ e $2.510,80 \mathrm{~kJ} \mathrm{~kg}^{-1}$ para os teores de água de 4,51 a $13,4 \%$ b.s., respectivamente. A entalpia e entropia diferencial estão intimamente conexas ao teor de água dos aquênios. A temperatura isocinética de 304,67 K denota a compensação química linear entre a entalpia e

${ }^{1} \mathrm{Dr}^{\mathrm{a}}$, Instituto Federal Goiano, IFGoiano, Rio Verde, GO, Brasil. E-mail: karinfebarbosa@gmail.com

2 Profs. Drs., IFGoiano, Rio Verde, GO, Brasil. E-mail: juliana.sales@ifgoiano.edu.br; osvresende@yahoo.com.br

3 Prof. Dr., IFGoiano, Iporá, GO, Brasil. E-mail: oliveira.d.e.c@gmail.com

${ }^{4}$ Prof $^{\mathrm{a}} \mathrm{Dr}^{\mathrm{a}}$, Instituto Federal de Mato Grosso do Sul, IFMS, Aquidauana, MS, Brasil. E-mail: ana.cabral@ifms.edu.br

5 Discente, Curso de Doutorado, Programa de Pós-Graduação em Fitossanidade, Universidade Federal de Goiás, UFG, Goiânia, GO, Brasil. E-mail: lopesfilholuizcesar@gmail.com

* Author for correspondence 
a entropia diferenciais dos aquênios de cajuzinho-do-cerrado, sendo o processo de dessorção controlado pela entalpia.

Palavras-chave: Atividade de água. Calor latente. Entalpia. Entropia. Energia livre.

\section{Introduction}

Anacardium humile St. Hil., popularly known as 'cajuzinho-do-cerrado' or 'cajuí', is a shrub with a height of 0.60 to $0.80 \mathrm{~m}$. The accessory fruit is yellowish red; one plant can produce 10 to 50 fruits, and fruiting occurs from December to February (SILVA et al., 2001).

The Anacardium humile St. Hil. may be consumed fresh or be processed to separate the juice and pulp. The juice is used for soft drinks and beverages, the pulp is used for jams and sweets, and the nut may be consumed roasted (ALMEIDA, 1998).

The cajuzinho-do-cerrado is a native species of the cerrado of great potential of use and is threatened of extinction. The fruit and the peseudofruit are very appreciated and it is part of the local food, the fruit in turn can be stored in natura and commercialized.

The ideal moisture content of the product along the storage is essential in establishing the conservation of the quality characteristics of the agricultural product (OLIVERIRA et al., 2014). The study of the thermodynamic properties in the drying processes of agricultural products is of paramount importance to study the properties of the adsorbed water and the science of the physical phenomena that occur in the food surface (CORRÊA et al., 2010).

Knowledge of the water sorption isotherms and the net isosteric sorption heat is important for the drying, storage and packaging processes. These parameters are useful for calculating the time and energy consumed during drying and for predicting the behaviour of the product. They are also useful when determining the shelf life of food products (SIRIPATRAWAN; JANTAWAT, 2006; COMUNIAN et al., 2011; CATELAM et al., 2011).
The thermodynamic properties of water desorption, such as differential enthalpy, differential entropy and the Gibbs free energy variation, may be defined using the hygroscopic equilibrium isotherms and are essential for the energy determination and prediction of kinetic processes in drying methods (KAYA; KAHYAOGLU, 2006).

The Gibbs free energy of an agricultural product, of thermodynamic understanding, portrays the maximum amount of energy released in a process at constant temperature and pressure which is free to perform useful work. That is, the equilibrium between enthalpy and entropy (BASTOS, 2009).

Thus, the objective of this study was to determine and evaluate the thermodynamic properties of Anacardium humile St. Hil.achenes for various temperatures and hygroscopic equilibrium points.

\section{Materials and Methods}

The experiment was conducted at the Laboratory of Vegetable Products Post-Harvest of the Federal Institute of Education, Science and Technology of Goiás - Rio Verde Campus. The Anacardium humile St. Hil. fruits were collected manually when they were fully mature in the municipality of Mineiros, Goiás, Brazil, at latitude $18^{\circ} 6^{\prime} 23^{\prime \prime} \mathrm{S}$ and longitude $52^{\circ} 55^{\prime} 40^{\prime \prime}$ and at an altitude of $820 \mathrm{~m}$.

The fruits were de-pulped and the achenes separated with the aid of a nylon string. The achenes were then washed in plastic trays in $2 \%$ sodium hypochlorite solution for $5 \mathrm{~min}$. After the fruits had been washed, the initial moisture content of the achenes was determined ( $28 \%$ wet basis [wb]), and the seeds were dried in silica gel at $25 \pm 2{ }^{\circ} \mathrm{C}$ until reaching a moisture content of $13.4,11.1,8.7$ and $5.3(\% \mathrm{db})$. 
The moisture content was determined for four subsamples of $5 \mathrm{~g}$ each using the oven method at $105 \pm 3{ }^{\circ} \mathrm{C}$ for 24 hours according to the Brazilian Rules for Seed Analysis (BRASIL, 2009).

The Copace model was used to determine the thermodynamic properties of the Anacardium humile St. Hil. achenes, according to Barbosa et al. (2016), by means of the following expression:

$\mathrm{Xe}=\exp \left\{0.104428-(0.005207 \cdot \mathrm{T})+\left[1.18396 \cdot \exp \left(\mathrm{a}_{\mathrm{w}}\right)\right]\right\}$

where

Xe: equilibrium moisture content, $\% \mathrm{db}$;

$\mathrm{a}_{\mathrm{w}}$ : water activity, decimal; and

$\mathrm{T}$ : temperature, ${ }^{\circ} \mathrm{C}$.

Othmer, cited by Brooker et al. (1992) from the studies of Clausius-Clapeyron, proposed the following equation to quantify the partial vapour pressure of porous systems:

$$
\operatorname{Ln}\left(\mathrm{Pv}_{\mathrm{v}}\right)=\left(\frac{\mathrm{L}}{\mathrm{L}^{\prime}}\right) \cdot \operatorname{Ln}(\mathrm{Pvs})+\mathrm{C}
$$

where

Pvs: free water saturation vapour pressure at a given equilibrium temperature $(\mathrm{T}), \mathrm{Pv}$ : free water vapour pressure at a certain equilibrium temperature, $\mathrm{L}$ : latent heat of water vaporization of the product at the equilibrium temperature $\left(\mathrm{kJ} \mathrm{kg}^{-1}\right)$, and

$\mathrm{C}$ : integration constant.

The value of the L/L' ratio of Equation 3 was determined based on the sorption isotherms of the Anacardium humile St. Hil. achenes according to the method described by Pereira and Queiroz (1987) for the different equilibrium moisture contents, $\mathrm{Xe}$ (decimal). The equation was adjusted for the enthalpy of water vaporization, given by RodriguesArias (BROOKER et al., 1992), with the addition of one more parameter in Equation 3 to improve the L/L' ratio estimates (CORRÊA et al., 1998):

$$
\frac{\mathrm{L}}{\mathrm{L}^{\prime}}-1=\mathrm{a} \cdot \operatorname{Exp}\left(-\mathrm{b} \cdot \mathrm{Xe}^{\mathrm{m}}\right)
$$

where

$a, b$ and $m$ are the parameters that depend on the product.

The latent heat of vaporization of free water $\left(\mathrm{kJ} \mathrm{kg}^{-1}\right)$ at the equilibrium temperature $\left({ }^{\circ} \mathrm{C}\right)$ was estimated using the mean temperature $(\mathrm{T})$ in the range under study, using the following equation:

$$
\mathrm{L}=2502.2-2.39 \cdot \mathrm{T}
$$

The saturation vapour pressure of free water, Pvs, was obtained using the Thétens equation:

$$
\left.\operatorname{PVS}=0.61078 \cdot 10^{((7.5 \cdot \mathrm{T}) /(273.3+\mathrm{T})}\right)
$$

The vapour pressure value, $\mathrm{Pv}$, was determined according to the following equation:

$$
\mathrm{Pv}=\mathrm{a}_{\mathrm{w}} \cdot \mathrm{Pvs}
$$

Combining Equations 3 and 4 leads to the following expression, used to estimate the latent heat of water vaporization of the product (CORREA et al., 1998):

$\mathrm{L}=(2502.2-2.39 \cdot \mathrm{T}) \cdot\left[1+\mathrm{a} \cdot \operatorname{Exp}\left(-\mathrm{b} \cdot \mathrm{Xe}^{\mathrm{m}}\right)\right](7)$

The differential entropy of sorption was calculated using the Gibbs-Helmholtz equation according to the following expression (RIZVI, 1995):

$$
\Delta \mathrm{S}=\frac{\Delta \mathrm{h}_{\mathrm{st}}-\Delta \mathrm{G}}{\mathrm{T}_{\mathrm{a}}}
$$

where

$\Delta \mathrm{S}$ : differential entropy of sorption $\left(\mathrm{kJ} \mathrm{kg}^{-1} \mathrm{~K}^{-1}\right)$, $\Delta \mathrm{h}_{\mathrm{st}}$ : differential enthalpy $\left(\mathrm{kJ} \mathrm{kg}^{-1}\right), \mathrm{T}_{\mathrm{a}}$ is the 
absolute temperature $(\mathrm{K})$, and

$\Delta \mathrm{G}$ : Gibbs free energy $\left(\mathrm{kJ} \mathrm{kg}^{-1}\right)$.

The Gibbs free energy may be calculated using the following equation:

$$
\Delta \mathrm{G}=-\mathrm{R} \cdot \mathrm{T} \cdot \mathrm{Ln} \mathrm{a}_{\mathrm{w}}
$$

where

$\mathrm{R}$ : universal gas constant, $8.314 \mathrm{~kJ} \mathrm{kmol}^{-1} \mathrm{~K}^{-1}$, with water vapour being $0.4619 \mathrm{~kJ} \mathrm{~kg}^{-1} \mathrm{~K}^{-1}$.

The effects of changes in water sorption over free energy are accompanied by changes in the enthalpy and entropy values. Thus, replacing Equations 8 in 9 and rearranging, we have:

$$
\operatorname{Ln}\left(\mathrm{a}_{\mathrm{w}}\right)=\frac{\Delta \mathrm{h}_{\mathrm{st}}}{\mathrm{R} \cdot \mathrm{T}_{\mathrm{a}}}-\frac{\Delta \mathrm{S}}{\mathrm{R}}
$$

The enthalpy $\left(\Delta_{\mathrm{hst}}\right)$ and differential sorption $(\triangle \mathrm{S})$ values were estimated from Equation 11 (BERISTAIN et al., 1996):

$$
\Delta \mathrm{h}_{\mathrm{st}}=\mathrm{T}_{\mathrm{B}}(\Delta \mathrm{S})+\Delta \mathrm{G}_{\mathrm{B}}
$$

where

$\mathrm{T}_{\mathrm{B}}$ : isokinetic temperature $(\mathrm{K})$ and $\Delta \mathrm{G}_{\mathrm{B}}$ : Gibbs free energy at the isokinetic temperature $\left(\mathrm{kJ} \mathrm{kg}^{-1}\right)$.

The isokinetic temperature indicates a series of reactions occurring at the same rate. Since enthalpy and entropy are strongly correlated, the compensation theory is assumed to be valid for sorption (BERISTAIN et al., 1996). To confirm the existence of compensation, the isokinetic temperature was compared with the harmonic mean of the temperatures used to determine the sorption isotherms, according to Equation 12 (KRUG et al., 1976a, 1976b):

$$
\mathrm{T}_{\mathrm{hm}}=\frac{\mathrm{n}}{\sum\left(\frac{1}{\mathrm{~T}}\right)}
$$

where

$\mathrm{T}_{\mathrm{hm}}$ : harmonic mean of the temperature $(\mathrm{K})$ and $\mathrm{n}$ : number of temperatures used.

According to Krug et al. (1976a, 1976b), linear chemical compensation or compensation theory exists only if the isokinetic temperature $\left(\mathrm{T}_{\mathrm{B}}\right)$ is different from the harmonic mean temperature $\left(\mathrm{T}_{\mathrm{hm}}\right)$. An approximate confidence interval, (1- $\left.\alpha\right)$ $100 \%$, was calculated for the isokinetic temperature using the following equation:

$$
\mathrm{T}_{\mathrm{B}}=\hat{\mathrm{T}} \pm \mathrm{t}_{\mathrm{m}-2, \alpha / 2 \sqrt{\operatorname{Var}\left(\mathrm{T}_{\mathrm{B}}\right)}}
$$

where

$$
\hat{\mathrm{T}}_{\mathrm{B}}=\frac{\sum\left(\Delta \mathrm{h}_{\mathrm{st}}-\overline{\Delta \mathrm{h}_{\mathrm{st}}}\right)(\Delta \mathrm{S}-\overline{\Delta \mathrm{S}})}{\sum(\Delta \mathrm{S}-\overline{\Delta \mathrm{S}})^{2}}
$$

and

$$
\operatorname{Var}\left(\mathrm{T}_{\mathrm{B}}\right)=\frac{\sum\left(\Delta \mathrm{h}_{\mathrm{st}}-{\overline{\Delta \mathrm{G}_{\mathrm{B}}}}-\hat{\mathrm{T}}_{\mathrm{B}} \Delta \mathrm{S}\right)^{2}}{(\mathrm{~m}-2) \sum(\Delta \mathrm{S}-\overline{\Delta \mathrm{S}})^{2}}
$$

where

m: number of enthalpy and entropy data pairs,

$\overline{\Delta \mathrm{h}_{\mathrm{st}}}$ : mean enthalpy, $\mathrm{kJ} \mathrm{kg}^{-1}$, and $\overline{\Delta \mathrm{S}}$ : mean entropy $\mathrm{kJ} \mathrm{kg}^{-1}$.

If the harmonic mean of the temperature $T_{h m}$ is within the calculated interval of the isokinetic temperature $T_{B}$, the relation between the differential sorption enthalpy and entropy reflects only experimental errors and not the existence of chemical and physical factors governing the compensation theory (BERISTAIN et al., 1996). A 99\% confidence interval for the range of experimental data was adopted for $T_{B}$. 


\section{Results and Discussion}

Table 1 shows the water activity data estimated by the Copace model (Equation 1) for equilibrium moisture content between 4.51 and $13.40(\% \mathrm{db})$ and for temperatures of $10,20,30$ and $40{ }^{\circ} \mathrm{C}$.

For the same moisture content, an increase in water activity as the temperature increased was observed, a characteristic that can be compared with those obtained in the seeds of Astrocaryum huaimi Mart. ('tucumã-de-goiás') (OLIVEIRA et al., 2011). By contrast, Coriandrum sativum (coriander) leaves show a decrease in water activity as the temperature increases (SILVA et al., 2010). These data demonstrate different hygroscopic behavior for each type of agricultural product, expressing equilibrium moisture content as a function of temperature.

The values of the $\mathrm{L} / \mathrm{L}$ ' ratio for the different moisture contents are shown in Table 2. Importantly, as the moisture content decreases, an increase occurs in the $\mathrm{L} / \mathrm{L}$ ' ratio, showing a correlation between the increase in the moisture contents and a reduction in the $\mathrm{L} / \mathrm{L}$ ' ratio.

Table 1. Values of water activity (decimal) estimated by the Copace model as a function of desorption temperatures and equilibrium moisture content for Anacardium humile St. Hil.

\begin{tabular}{ccccc}
\hline \multirow{2}{*}{ Moisture content $(\% \mathrm{db})$} & \multicolumn{4}{c}{ Temperature } \\
\cline { 2 - 5 } & 10 & 20 & 30 & 40 \\
\hline 4.5 & 0.2051 & 0.2403 & 0.2743 & 0.3072 \\
4.5 & 0.2064 & 0.2416 & 0.2755 & 0.3084 \\
5.3 & 0.3059 & 0.3378 & 0.3687 & 0.3987 \\
5.3 & 0.3087 & 0.3405 & 0.3713 & 0.4012 \\
5.5 & 0.3297 & 0.3609 & 0.3911 & 0.4204 \\
6.1 & 0.3942 & 0.4234 & 0.4518 & 0.4794 \\
9.6 & 0.6251 & 0.6484 & 0.6711 & 0.6934 \\
9.7 & 0.6305 & 0.6536 & 0.6762 & 0.6984 \\
9.8 & 0.6345 & 0.6575 & 0.6800 & 0.7021 \\
10.8 & 0.6753 & 0.6975 & 0.7191 & 0.7403 \\
12.4 & 0.7330 & 0.7539 & 0.7744 & 0.7945 \\
13.4 & 0.7634 & 0.7837 & 0.8036 & 0.8231 \\
13.40 & 0.7646 & 0.7848 & 0.8047 & 0.8242 \\
\hline
\end{tabular}

Table 2. L/L' ratios for the different moisture contents of Anacardium humile St. Hil. achenes.

\begin{tabular}{cccc}
\hline $\mathrm{Xe}(\% \mathrm{db})$ & $\mathrm{L} / \mathrm{L}$ & $\mathrm{Xe}(\% \mathrm{db})$ & $\mathrm{L} / \mathrm{L}$ \\
\hline 4.51 & 1.2253 & 9.74 & 1.057 \\
4.52 & 1.2239 & 9.83 & 1.0565 \\
5.26 & 1.1477 & 10.79 & 1.0512 \\
5.28 & 1.1462 & 12.39 & 1.0449 \\
5.47 & 1.1355 & 13.37 & 1.042 \\
6.10 & 1.1092 & 13.40 & 1.0419 \\
9.63 & 1.0578 & &
\end{tabular}


The parameters ' $a$ ', 'b' and ' $m$ ' are shown in Table 3 and were used to calculate the ratio between the latent heat of vaporization of agricultural products and the latent heat of free water (L/ L'), obtained by non-linear regression. The equation used was satisfactory in describing the phenomenon, as its parameters and the coefficient of determination (R2) were highly significant. Therefore, the equation cannot be used to define the latent heat of the vaporization of the water in the Anacardium humile St. Hil. achenes.

Table 3. Parameters ' $a$ ', ' $b$ ' and ' $m$ ' used to calculate the ratio between the latent heat of water vaporization of agricultural products and the latent heat of the free water $(\mathrm{L} / \mathrm{L}$ ').

\begin{tabular}{cccc}
\hline $\mathrm{A}$ & $\mathrm{B}$ & $\mathrm{m}$ & $\mathrm{R}^{2}(\%)$ \\
\hline 0.0279 & -17.9898 & -1.4308 & 99.98 \\
\hline
\end{tabular}

Figure 1 shows the curves of the latent heat of the water vaporization of the Anacardium humile St. Hil. achenes at the temperatures of 10, 20, 30 and $40{ }^{\circ} \mathrm{C}$. The values ranged from $3,035.63$ to $2,510.80 \mathrm{~kJ} \mathrm{~kg}^{-1}$ for moisture contents from 4.51 to $13.4 \% \mathrm{db}$; as the equilibrium moisture content decreases, the energy required for the evaporation of water in the Anacardium humile St. Hil. achenes increases. The latent heat of vaporization decreases as the temperature for the same moisture content increases.

Figure 1. Experimental and estimated values of the latent heat of water vaporization in Anacardium humile St. Hil. achenes as a function of the equilibrium of the moisture content for the temperatures of $10,20,30$ and $40{ }^{\circ} \mathrm{C}$.

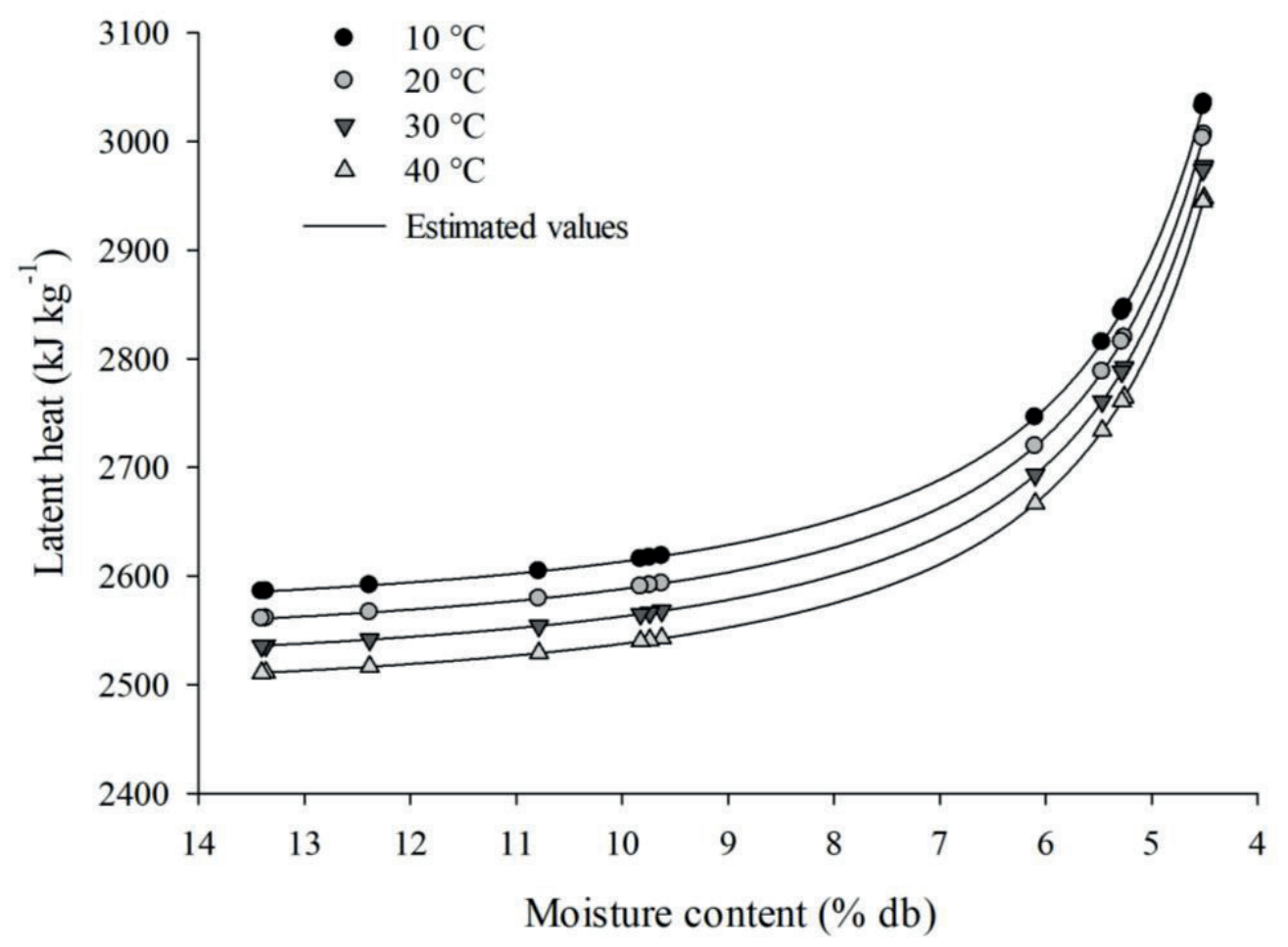


These values corroborate those found in Triticum (wheat) grains by Corrêa et al. (2006), who obtained the lowest amount of energy necessary to evaporate the water, calculated for the temperature of $40{ }^{\circ} \mathrm{C}$, which resulted in a value of $2,406.60 \mathrm{~kJ} . \mathrm{kg}^{-1}$. In the case of grains of Zea mays L. (corn), according to the decrease of the equilibrium water content, there was an increase in the energy required for the evaporation of water from the grains (SMANIOTTO et al., 2012). Moreover, the moisture content in which the isosteric heat of sorption approximates the latent heat of free water vaporization is commonly analysed as the free moisture content in the product (MULET et al., 2002).

Figure 2 shows the differential enthalpy and entropy of desorption values of the achenes. These characteristics are closely related to the moisture content of the seeds, with values of 0.238 to 1.219 $\mathrm{kJ} \mathrm{kg}^{-1}$ being obtained for entropy and values of 102.47 to $551.45 \mathrm{~kJ} \mathrm{~kg}^{-1}$ for the differential enthalpy of desorption for the moisture content range studied. Similar results were obtained by Oliveira et al. (2014) in Jatropha curcas L (physic nut) seeds.

Lower enthalpy values demonstrate less energy required to remove the water bound to the product during drying (OLIVEIRA et al., 2010). However, entropy is associated with the degree of disorder, being a state function in which its values increase during a natural process in an isolated system (GONELI et al., 2010).

The enthalpy-entropy ratio for the water desorption process that is presented in Figure 3 can be represented by linear regression, presenting a high coefficient of determination (99.69\%). Because a high degree of linearity exists between the differential enthalpy $(\Delta \mathrm{hst})$ and differential entropy $(\Delta \mathrm{S})$ of the desorption values, the enthalpy-entropy compensation theory or isokinetic theory for the phenomenon of water desorption of the Anacardium humile St. Hil. achenes can be considered valid.

Figure 2. Experimental and estimated values of differential enthalpy and entropy of desorption in Anacardium humile St. Hil. achenes.

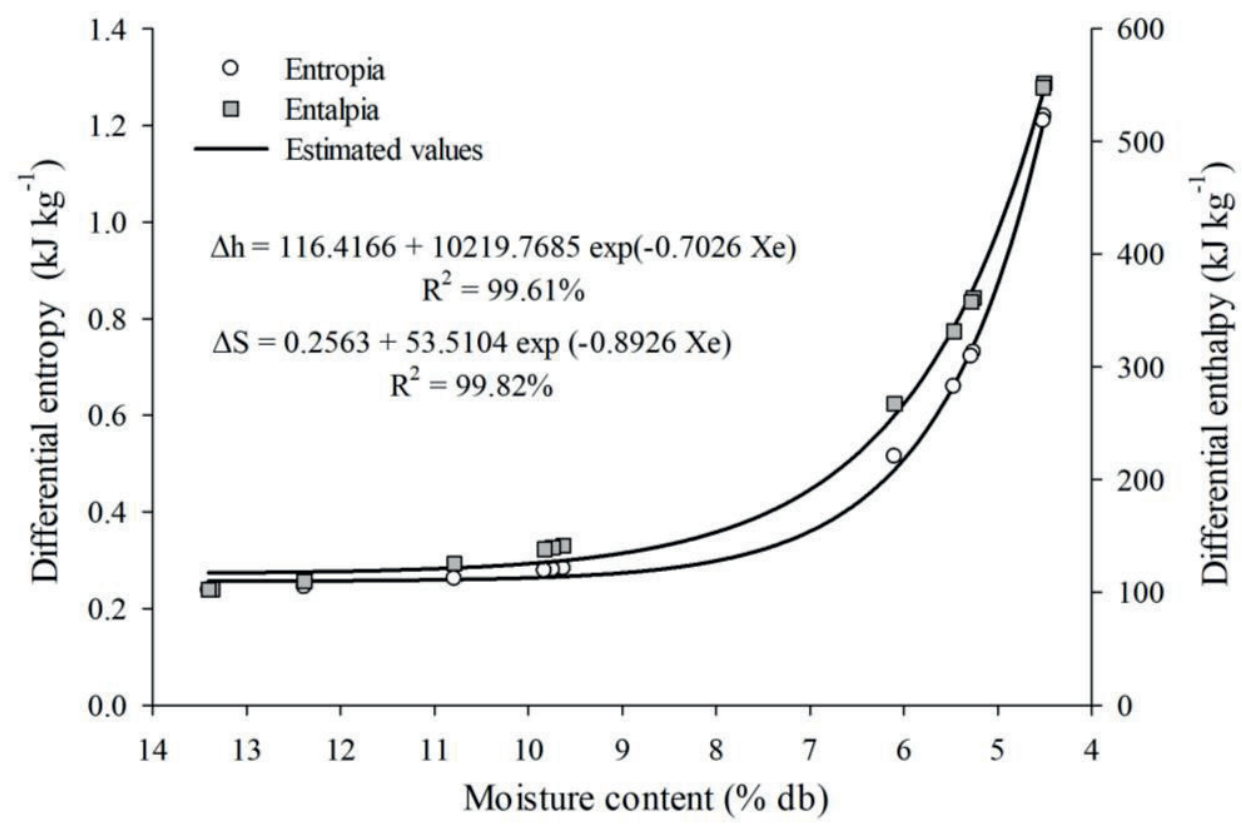


Figure 3. Enthalpy-entropy ratio for water desorption in Anacardium humile St. Hil. achenes.

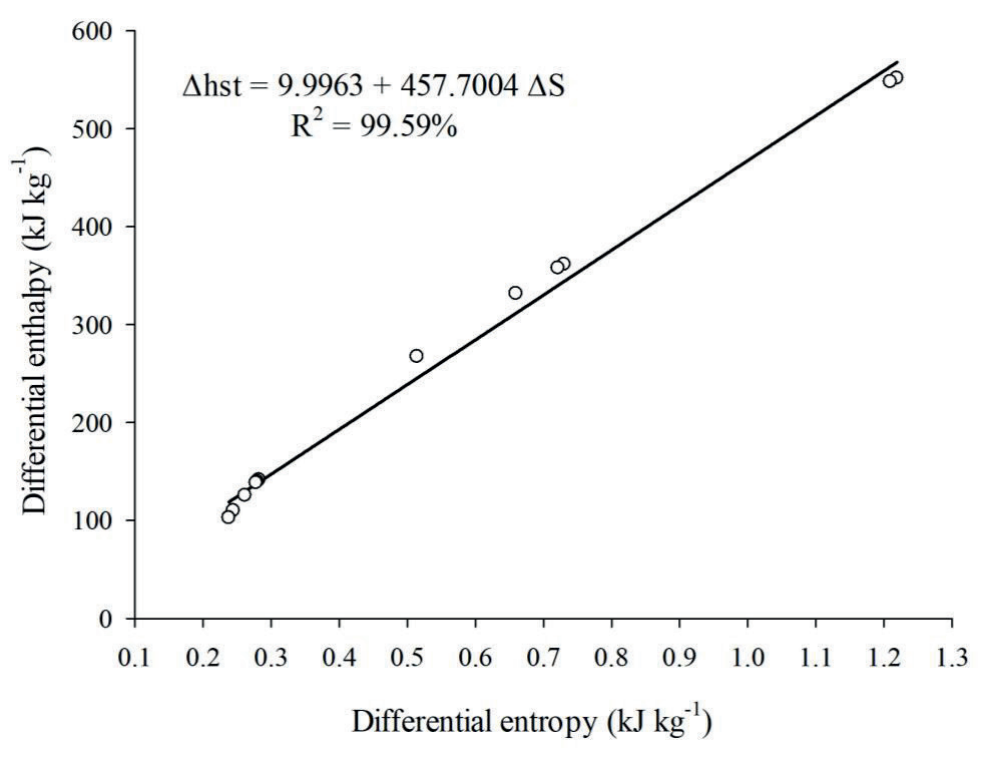

The existence of the compensatory theory indicates that only one reaction mechanism is followed by all the components of the reaction series, and therefore, a safe judgement of the isokinetic relation supports the clarification of the reaction mechanism (GARCÍA-PÉREZ et al., 2008).

In Figure 4, the Gibbs free energy is presented as a function of the moisture content for each temperature during the desorption process of the Anacardium humile St. Hil. achenes. As the equilibrium moisture content decreases, an increase is observed in the Gibbs free energy, and for a constant moisture content, the Gibbs free energy increases as the temperature decreases. The values obtained ranged from 207.22 to 27.97 for moisture contents from 4.51 to 13.40 , respectively.

Figure 4. Gibbs free energy as a function of the moisture content of Anacardium humile St. Hil. achenes.

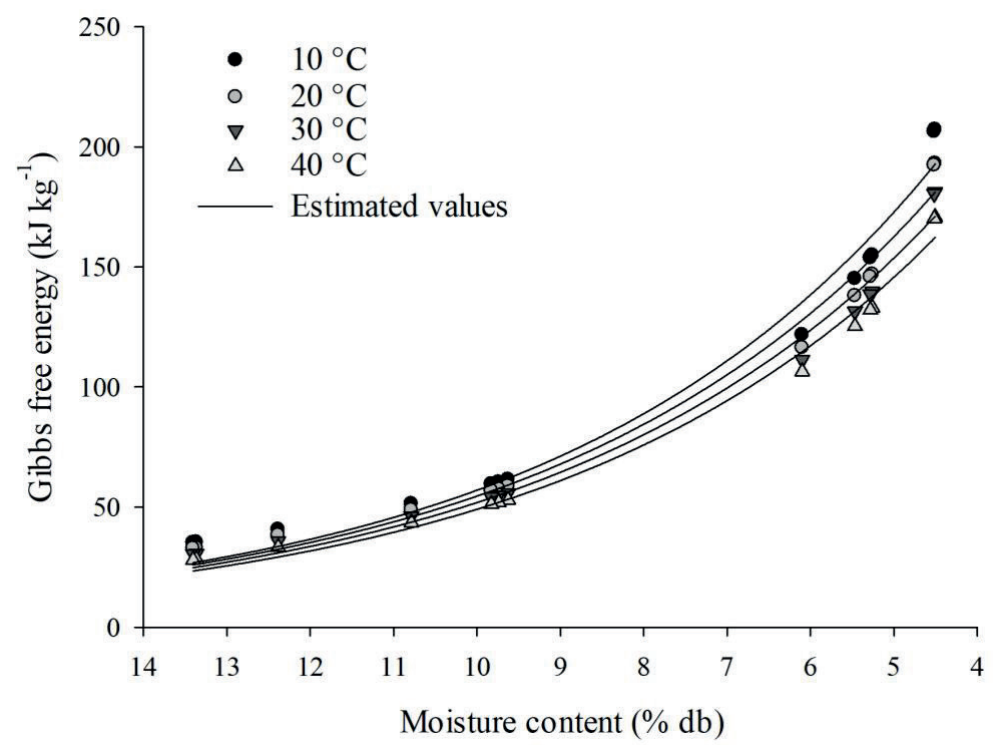


In thermodynamics, the Gibbs free energy is manifested as a thermodynamic potential that assesses the initial work achieved by means of an isothermal process in an isobaric system. The changes in free energy are a consequence of water absorption, which are commonly followed by changes in enthalpy and entropy (GARCÍA et al., 2008).

\section{Conclusion}

The latent heat of vaporization of water increases with the decrease in the equilibrium moisture content, varying between $3,035.63$ and 2,510.80 $\mathrm{kJ} \mathrm{kg}^{-1}$ for the moisture contents of 4.51 to $13.4 \%$ $\mathrm{db}$, respectively. The isokinetic temperature of $304.67 \mathrm{~K}$ denotes the linear chemical compensation between the differential enthalpy and entropy of the achenes, and the desorption process is controlled by enthalpy.

\section{Acknowledgements}

We acknowledge the Brazilian National Council of Scientific and Technological Development (Conselho Nacional de Desenvolvimento Científico e Tecnológico - CNPQ) for granting the scholarship and the Studies and Projects Financing Agency (Financiadora de Estudos e Projetos - FINEP) for the funding.

The authors extend thanks to IF Goiano for their financial support, which was indispensable to the execution of this study.

\section{References}

ALMEIDA, S. P.; PROENÇA, C. E. B.; SANO, S. M.; RIBEIRO, J. F. Cerrado: espécies vegetais úteis. Planlatina: EMBRAPA. 1998. 464 p.

BARBOSA, K. F.; SALES, J. de F.; RESENDE, O.; OLIVEIRA, D. E. C.; ZUCHI, J.; SOUSA, K. A. Isotermas de dessorção e calor isostérico de aquênios de cajuzinho-do-cerrado. Revista Brasileira de Engenharia Agrícola e Ambiental, Campina Grande, v. 20, n 5, p.
481-486, 2016.

BASTOS, S. M. C. Propriedades termodinâmicas e adsorção de água de dois genótipos de arroz vermelho. 2009. Dissertação (Mestrado em Engenharia Agrícola) Universidade Estadual de Goiás, Anápolis.

BERISTAIN, C. I.; GARCIA, H. S.; AZUARA, E. Enthalpy-entropy compensation in food vapor adsorption. Journal of Food Engineering, Davis, v. 30, n. 3-4, p. 405415, 1996.

BRASIL. Ministério da Agricultura e Reforma Agrária. Secretaria Nacional de defesa Agropecuária. Regras para análise de sementes. Brasília: Mapa/ACS, 2009. 399 p.

BROOKER, D. B.; BAKER-ARKEMA, F. W.; HALL, C. W. Drying and storage of grains and oilseeds. New York: AVI Book, 1992. 450 p.

CATELAM, K. T.; TRINDADE, C. S. F.; ROMERO, J. T. Adsorption isotherms and isosteric heat in passionfruit pulp dehydrated using a spray dryer and freeze dryer with additives and skim milk. Ciência e Agrotecnologia, Lavras, v. 35, n. 6, p. 1196-1203, 2011.

COMUNIAN, T. A.; MONTERREY-QUINTERO, E. S.; THOMAZINI, M.; BALIEIRO, J. C. C.; PICCONE, P.; PITTIA, P.; FAVARO-TRINDADE, C. S. Assessment of production efficiency, physicochemical properties and storage stability of spray-dried chlorophyllide, a natural food colourant, using gum Arabic, maltodextrin and soy protein isolate based carrier systems. International Journal of Food Science and Technology, Londres, v. 46, n. 6, 1259-1265, 2011.

CORRÊA， P. C.; CHRIST, D.; MARTINS, J. H.; MANTOVANI, B. H. M. Curvas de dessorção e calor latente de vaporização para as sementes de milho pipoca. Revista Brasileira de Engenharia Agrícola e Ambiental, Campina Grande, v. 2, n. 1, p. 7-11, 1998.

CORRÊA, P. C.; OLIVEIRA, G. H. H.; BOTELHO, F. M.; GONELI, A. L. D.; CARVALHO, F. M. Modelagem matemática e determinação das propriedades termodinâmicas do café (Coffea arabica L.) durante o processo de secagem. Revista Ceres, Viçosa, MG, v. 57, n. 5 , p. 595-601, 2010.

CORRÊA, P. C.; RIBEIRO, D. M.; RESENDE, O.; BOTELHO, F. M. Determinação e modelagem das propriedades físicas e da contração volumétrica do trigo, durante a secagem. Revista Brasileira de Engenharia Agrícola e Ambiental, Campina Grande, v. 10, n. 3, p. 665-670, 2006.

GARCÍA, C. F.; MOYANO, P. C.; PEDRESCHI, F. Enthalpy-entropy compensation for water loss of vegetable tissues during air-drying. Drying Technology, New York, v. 26, n. 10-12, p. 1563-1569, 2008. 
GARCÍA-PÉREZ, J. V.; CÁRCEL, J. A.; CLEMENTE, G.; MULET, A. Water sorption isotherms for lemon peel at different temperatures and isosteric heats. Food Science and Technology, Davis, v. 41, n. 1, p. 18-25, 2008.

GONELI, A. L. D.; CORRÊA, P. C.; OLIVEIRA, G. H. H.; BOTELHO, F. M. Water desorption and thermodynamic properties of okra seeds. Transaction of ASAE, St. Joseph, v. 53, n. 1, p. 191-197, 2010.

KAYA, S.; KAHYAOGLU, T. Influence of dehulling and roasting process on the thermodynamics of moisture adsorption in sesame seed. Journal of Food Engineering, Davis, v. 76, n. 2, p. 139-147, 2006.

KRUG, R. R.; HUNTER, W. G.; GRIEGER, R. A. Enthalpy-entropy compensation: 1 - some fundamental statistical problems associated with the analysis of Van't Hoff and Arrhenius data. Journal of Physical Chemistry, Washington, v. 80, n. 21, p. 2335-2341, 1976a.

Enthalpy-entropy compensation: 2 separation of the chemical from the statistical effect. Journal of Physical Chemistry, Washington, v. 80, n. 21, p. 23412351, 1976b.

MULET, A.; GARCYA-PASCUAL, P.; SANJUÁN, N.; GARCIA-REVERTER, J. Equilibrium isotherms and isosteric heats of morel (Morchella esculenta). Journal of Food Engineering, Davis, v. 53, n. 1, p. 75-81, 2002.

OLIVEIRA, D. E. C.; RESENDE, O.; CHAVES, T. H.; SOUZA, K. A. M.; SMANIOTTO, T. A. S. Propriedades termodinâmicas das sementes de pinhão-manso. Bioscience Journal, Uberlândia, v. 30, n. 147-157, 2014.

OLIVEIRA, G. H. H.; CORRÊA, P. C.; ARAÚJO, E. F.; VALENTE, D. S. M.; BOTELHO, F. M. Desorption isotherms and thermodynamic properties of sweet corn cultivars (Zea mays L.). International Journal of Food Science and Technology, Londres, v. 45, n. 3, p. 546-554, 2010.

OLIVEIRA, G. H. H.; CORREAA, P. C.; SANTOS, E. S. S.; TRETO, P. C.; DINIZ, M. D. M. S. Evaluation of thermodynamic properties using GAB model to describe the desorption process of cocoa beans. International Journal of Food Science and Technology, Londres, v. 46, n. 10, p. 2077-2084, 2011.

PEREIRA, I. A. M.; QUEIROZ, D. M. de. Higroscopia. Viçosa, MG: Centreinar, 1987. 28 p.

RIZVI, S. S. H. Thermodynamic properties of foods in dehydration. In: RAO, M. A.; RIZVI, S. S. H. Engineering properties of foods. New York: Academic Press, 1995. p. 223-309.

SILVA, A. S.; ALMEIDA, F. A. C.; ALVES, N. M. C.; MELO, K. S. Característica higroscópica e termodinâmica do coentro desidratado. Revista Ciência Agronômica, Fortaleza, v. 41, n. 2, p. 237-244, 2010.

SILVA, D. B.; SILVA, J. A.; JUNQUEIRA, N. T. V.; ANDRADE, L. R. M. Frutas do cerrado. Brasília: EMBRAPA, 2001. 178 p.

SIRIPATRAWAN, U.; JANTAWAT, P. Determination of moisture sorption isotherms of jasmine rice crackers using BET and GAB models. Food Science and Technology International, Los Angeles, v. 6, n. 12, p. 459-465, 2006.

SMANIOTTO, T. A. de S.; RESENDE, O.; OLIVEIRA, D. E. C.; SOUSA, K. A.; CAMPOS, R. C. Isotermas e calor latente de dessorção dos grãos de milho da cultivar AG 7088. Revista Brasileira de Milho e Sorgo, Sete Lagoas, v. 11, n. 3, p. 312-322, 2012. 